\title{
MODEL IMPLEMENTASI MANAJEMEN KERJASAMA UNTUK MENCEGAH DAN MEMINIMALISIR PERKELAIHAN ANTAR PELAJAR DI KECAMATAN PARUNG - KABUPATEN BOGOR
}

\author{
Wiyanto ${ }^{1}$, Bachtiar Arifudin Husain ${ }^{2}$ \\ dosen01840@unpam.ac.id
}

\begin{abstract}
Abstrak: Perkelahian antar pelajar merupakan suatu realita (nyata) terjadinya degradasi moral (merosotnya karakter) bagi generasi penerus bangsa Indonesia. Perkelaihan antar pelajar di Kabupaten Bogor sudah menjadi isu yang tidak asing lagi ditelinga masyarakat. Jalinan kerjasama antar berbagai pihak untuk mencegah dan meminimalisir terjadinya perkelahian antar pelajar sangat diperlukan. Tujuan dari penelitian ini adalah mengetahui proses dan model faktual penerapan manajemen kerjasama antara sekolah, orang tua dan polsek untuk mencegah dan meminimalisir perkelahian antar pelajar di Kecamatan Parung-Kabupaten Bogor. Metode yang digunakan dalam penelitian ini adalah kualitatif. Teknik pengumpulan data yang digunakan dalam penelitian ini adalah wawancara mendalam (indep interview), observasi dan dokumentasi. Untuk menguji keabsahan data digunakan teknik triangulasi. Analisis data dilakukan melalui empat tahapan yakni (1) pengumpulan data; (2) Reduksi data; (3) penyajian data dan (4) verifikasi dan penarikan kesimpulan. Hasil penelitian menunjukkan bahwa Manajemen kerjasama yang dibangun oleh polsek, sekolah dan orang tua dalam bentuk formal maupun non formal dengan sebuah wadah bernama satgas pelajar. Kerjasama yang dibangun direncanakan, diorganisasikan, dilaksanakan dan dievaluasi. Hadirnya satgas pelajar terbukti mampu mencegah dan meminimalisisr tawuran pelajar. Model faktual manajemen kerjasama dapat dijadikan rujukan setiap daerah untuk mengatasi tawuran pelajar.
\end{abstract}

Kata Kunci: Manajemen Kerjasama, Tawuran Pelajar, POLSEK, Sekolah, Orang Tua

\section{PENDAHULUAN}

Remaja atau pelajar adalah generasi penerus bangsa yang akan meneruskan estafet pembangunan nasional (I Gede Agung Sanjaya Suryawan, 2016:64). Remaja merupakan masa yang sarat akan konflik (Zainul Anwar, 2015:475). Bagi sebagian remaja masa tersebut sering menuai persoalan. Baik persoalan (konflik) pribadi maupun kaitanya dengan pergaulan dengan orang lain yang ada di lingkunganya.

\footnotetext{
12 Dosen Prodi Manajemen Fakultas Ekonomi Universitas Pamulang
} 
Remaja juga merupakan suatu tahapan pertumbuhan dan perkembangan dalam siklus hidup manusia. Masa remaja dimulai dari membangun jati diri untuk menunjukkan eksistensinya, memiliki kehendak bebas (Freewill untuk memilih), memegang teguh prinsip, dan mengembangkan kapasitasnya (Asmani, 2012:14). Melalui eksistensi yang dimiliki dan sedang dibangun, serta dengan kehendak bebas hampir seluruh waktu usia remaja digunakan untuk berinteraksi dengan lingkungan sosialnya. Berinteraksi dengan orang tua, guru, teman, dan lainya. Oleh karena itu, usia remaja merupakan usia dimana memiliki dorongan pergaulan yang sangat dinamis, sehingga masa remaja mudah untuk terpengaruh dengan lingkungan sekitarnya. Jika lingkungan tempat tinggal dan bergaul remaja positif, maka mereka akan terdorong untuk berkembang kearah positif. Begitu juga sebaliknya. Jika lingkungan tempat tinggal dan bergaul negatif maka ia juga akan dengan mudahnya terjerumus kepada hal yang negatif.

Keluarga didefinisikan sebagai jaringan orang-orang yang berbagi kehidupan mereka dalam jangka waktu yang lama, yang terikat oleh perkawinan, darah, atau komitmen, legal atau tidak, yang menganggap diri mereka sebagai keluarga, dan yang berbagi pengharapanpengharapan masa depan mengenai hubungan yang berkaitan (Galvin dan Bromel dalam Damayanti, 2013:49).

Keluarga juga merupakan lingkungan pertama kali yang dapat merubah pertumbuhan dan perkembangan anak-sejak lahir. Keluarga merupakan unit masyarakat terkecil sebagai tempat dimana kehidupan seorang individu dimulai dan paling banyak menghabiskan masa hidup. Keluarga yang seyogyanya menjadi tempat yang paling utama bagi setiap individu untuk beranung bukan hanya secara fisik dan namun juga psikologis (Damayanti 2013:48). Baru

kemudian lingkungan masyarakat, lingkungan sekolah dan lain-lain. Peran orang tua dalam pendidikan anak

diantaranya adalah menciptakan lingkungan belajar yang kondusif dirumah, ikut mengawasi kegiatan belajar anaknya mulai berangkat kesekolah, mengontrol belajar anaknya disekolah hingga pulang ke rumah. Dengan harapan anaknya dapat belajar dengan baik dan dapat meningkatkan prestasi anaknya.

Sudah tidak dapat dipungkiri bahwa pendidikan merupakan titik sentral dalam mengembangkan sumber daya manusia. Pendidikan adalah usaha sadar untuk menumbuh kembangkan potensi sumber daya manusia melalui kegiatan pembelajaran.

Berdasarkan Undang-Undang Nomor 20 Tahun 2003 tujuan pendidikan adalah untuk mengembangkan potensi peserta didik agar menjadi manusia yang beriman dan bertaqwa kepada Tuhan Yang Maha Esa, berahlak mulia, sehat, berilmu, cakap, kreatif, mandiri, dan menjadi warga Negara yang demokratis termasuk sekolah bertanggung jawab. Sekolah memegang peranan sentral untuk mewujudkan tujuan nasional tersebut.

Ketertbian dan kemanan dilingkungan masyarakat diemban oleh polisi. Karena polisi yang memegang amanah untuk hal itu yakni untuk menciptakan ketertiban dan keamanan 
masyarakat. Misalnya memberikan himbauan keamanan, keselamatan, ketertiban dan kelancaran dalam berlalu lintas, dan lain-lain.

Perkelahian antar pelajar merupakan suatu realita (nyata) terjadinya degradasi moral (merosotnya karakter) bagi generasi penerus bangsa Indonesia. Perkelaihan antar pelajar di Kabupaten Bogor sudah menjadi isu yang tidak asing lagi ditelinga masyarakat. Begitu juga media masa, liputan terkait perkelahian antar pelajar juga selalu mewarnai laman beritanya baik di media cetak maupun online.

Beberapa perkelahian antar pelajar yang terjadi dan yang tidak di masukkan di media masa juga kerap terjadi. Pernyataan tersebut sesuai dengan pengalaman pribadi peneliti. Bahkan dalam benak peneliti pribadi muncul pemikiran, polisi jaman dahulu yang biasa ditangkap adalah pelaku perjudian, pencurian, pembunuhan yang notabene orang-orang yang sudah tidak sekolah. Saat ini justru berbalik, yang ditangkap polisi adalah anak-anak sekolahan. Di Kecamatan Parung misalnya, Polsek Parung tidak jarang datang kesekolahsekolah untuk menjemput siswa-siswa yang terlibat dalam kasus tawuran. Baik itu siswa SMP maupun siswa SMK.

Perkelahian antar pelajar di Kecamatan Parung merupakan bentuk dari konflik terbuka dan bukan perilaku individu tetapi kelompok. Tidak jarang yang tidak memakan korban, mulai korban luka ringan, luka berat sampai pada nyawa melayang.

Faktor yang menyebabkan perkelahian antar pelajar di Kecamatan
Parung juga bermacam-macam mulai dari adanya nilai permusuhan dan perilaku bermusuhan dalam diri kelompok yang bertikai dan direproduksi setiap tahun oleh para seniornya. Sehingga mendorong munculnya perkelahian antar pelajar yang berkelanjutan, hamper setiap tahunya.

Oleh karena itu, jalinan kerjasama antar berbagai pihak untuk untuk mencegah dan meminimalisir terjadinya perkelahian antar pelajar sangat diperlukan. Kerjasama itu dapat dijalin antara sekolah, orang tua, masyarakat dan polsek setempat.

Istilah kerjasama berasal dari dua

kata, yaitu memorandum dan understanding. Secara gramatikal, memorandum of understanding diartikan sebagai nota kesepahaman (Heri Daryono, 2014:94). Sedangkan kata manajemen menurut kamus ekonomi adalah ilmu dan seni dalam perencanaan, pengorganisasian, pelaksanaan, dan pengawasan, penyusunan sumber daya manusia untuk mencapai tujuan yang telah ditetapkan (Nurul Oktima, 2012:183). Manajemen merupakan subyek yang sangat penting (Wardahana, 2007:8). Manajemen adalah suatu proses baik dalam tataran pikir maupun praktis secara individu untuk memimpin dirinya maupun kolektif untuk dirinya dan orang lain, memberikan bimbingan, serta mengarahkan orang-orang dalam suatu organisasi untuk mencapai tujuan yang telah ditentukan sebelumnya (Wiyanto, 2016:35). Sejalan dengan definisi tersebut, Oey Liang Lee (Ekonom dari Indonesia) dalam (Agung Feryanto, 2013:2) mengartikan manajemen adalah ilmu dan seni perencanaan, pengorganisasian, 
penyusunan, pengarahan, dan pengawasan sumber daya manusia untuk mencapai tujuan yang telah ditetapkan. Berdasarkan definisi tersebut nampaknya manajemen ditinjau dari proses, kolektifitas orang, ilmu, dan seni serta profesi. Berdasarkan pengertian tersebut dapat dikatakan bahwa manajemen kerjasama adalah impelemntasi teori manajemen dalam bidang kerjasama.

Kerjasama antara sekolah, orang tua, dan polsek setempat sangat penting untuk dilakukan khususnya terkait perkelaihan antar pelajar. Mengingat persoalan pekelahian antar pelajar ini adalah persoalan serius dan pelik, serta sudah masuk pada ranah kriminal. Maka diperlukan langkah-langkah dan strategi khusus antara sekolah, orang tua dan polsek setempat. Kerjasama itu tidak hanya dilakukan dalam bentuk nonformal saja, akan tetapi juga formal.

Tujuan dari penelitian ini adalah mengetahui proses dan model faktual penerapan manajemen kerjasama antara sekolah, orang tua dan polsek untuk mencegah dan meminimalisir perkelahian antar pelajar di Kecamatan ParungKabupaten Bogor.

\section{METODE PENELITIAN}

Metode yang digunakan dalam penelitian ini adalah kualitatif. Penelitian dilakukan hingga akhir 2018. Sumber data diperoleh dari: (1) informan sekolah, wali murid, dan polsek, serta dari peneliti sendiri sebagai informan kunci; (2) proses perencanaan, pengorganisasian, pelaksanaan dan pengawasan kerjasama antara sekolah, orang tua dan polsek. Teknik pengumpulan data yang digunakan dalam penelitian ini adalah wawancara mendalam (indep interview), observasi dan dokumentasi. Untuk menguji keabsahan data digunakan teknik triangulasi. Analisis data dilakukan melalui empat tahapan yakni (1) pengumpulan data; (2) Reduksi data; (3) penyajian data dan (4) verifikasi dan penarikan kesimpulan.

\section{HASIL DAN PEMBAHASAN}

Proses manajemen kerjasama antara sekolah, orang tua dan polsek untuk mencegah dan meminimalisir perkelahian antar pelajar di Kecamatan ParungKabupaten Bogor

Persoalan tawuran pelajar yang kerap kali terjadi di kecamatan ParungBogor mendorong seluruh elemen atau stakehoulder bersama-sama untuk ikut andil dalam mengatasi persoalan tersebut. Tawuran pelajar merupaka tidakan yang sangat membahayakan baik pelaku tawuran maupun warga masyarakat. Karena tawuran pelajar dipandang sebagai tindakan yang sangat meresahkan dan mengancam ketertiban dan keamanan di masyarakat. Semenjak peneliti berada di kecamatan parung sejak 2013 hingga sekarang, melihat tawuran pelajar di Kecamatan Parung layak mendapatkan perhatian yang sangat serius. Karena tawuran pelajar seolah menjadi sebuah tradisi musiman, sebuah ajang bagi anak muda untuk menunjukkan eksistensi dan mencari pengakuan diantara sesamanya. Tawuran pelajar merupakan tindakan kejahatan yang sangat menbahayakan bagi nyawa manusia. Karena tawuran pelajar tidak jarang sampai dengan menewaskan korban. 
Tawuran pelajar merupakan sebuah kejahatan karena mengandung unsur-unsur dengan perbuatan-perbuatan yang memiliki sifat diantaranya; dilakukan secara sengaja atau tidak sengaja, merugikan masyarakat karena mengganggu ketentraman masyarakat, melanggar hukum pidana serta diancam hukuman oleh negara misalnya dapat kita lihat dalam Kitab Undang-Undang Hukum Pidana (KUHP) Pasal 338 "barang siapa dengan sengaja merampas nyawa orang lain...." (pasal tersebut tentang pembunuhan).

Dalam persfektif sosiologis dapat kita cermati bahwa tawuran pelajar merupaka sebuah kejahatan karena merupakan perbuatan yang dapat dianggap sebagai tindakan anti sosial (karena ia hanya social terhadap komunitasnya. tetapi, mengesampingkan komunitas lain), amoral (karena tidak jarang yang harus adu cemoohan, adu senjata tajam, duel dan menghilangkan nyawa manusia), tidak dikehendaki oleh masyarakat, serta harus ditentang.

Jika kita lihat dari persfektif psikologis, tawuran pelajar merupakan sebuah perbuatan yang abnormal yang merupakan cerminan perilaku siswa yang terdidik yang dimana perilaku itu berkaitan dengan kejiwaan individu yang dianggap tidak selaras dengan normanorma dan nilai-nilai sosial yang ada di masyarakat. Secara psikologis tawuran pelajar lebih disebabkan oleh faktor kejiwaan. Aspek kejiwaan yang tidak sehatlah yang menyebabkan terjadinya tawuran pelajar. Aspek kejiwaan itu dapat kita identifikasi menjadi tiga hal. Pertama, episodic criminal, yakni pelajar melakukan tawuran disebabkan oleh dorongan emosi yang mendadak dan tidak terkendali. Pada kasus ini yang sering terjadi adalah disebabkan oleh faktor ejekejekan yang tidak terima.

Kedua, mental abnormal criminals yakni disebabkan oleh jiwa abnormal pelaku tawuran. Misalnya ia akan merasa bangga dan puas manakalah menang dalam tawuran. Kondisi abnormal terbentuk tidak sesaat merupakan hasil akumulasi dari tahun-tahun sebelumnya yang didominasi dan dipengaruhi oleh faktor lingkungan sosial dimana pelajar bergaul di masyarakat dan teman mainya. Ketiga adalah non malicious criminals, yakni pelajar melakukan tawuran tetapi menurut persfektif pelaku bukan merupakan perbuatan criminal atau kejahatan. Hal ini biasanya disebabkan oleh pemahaman pelajar yang kurang terkait tindakan-tindakan yang tergolong criminal dan merugikan masyarakat. Pemahaman yang benar perlu diberikan kepada pelajar terkait tindakan yang dilakukan itu boleh atau tidak boleh serta konsekuensi apa yang akan didapatkan. Bahkan tawuran pelajar ini sudah dapat dikatakan sebagai habitual criminal sudah menjadi kebiasaan yang dilakukan berulang ulang. Tawuran pelajar ini kerap kali terjadi pada awal tahun ajaran baru, akhir tahun ajaran menejelang kelulusan, bahkan setiap bulan, hanya saja gantiganti lokasi. Misalnya saja kejadian yang terjadi di sepanjang 2018 ini dimedia masa banyak berita tawuran pelajar yang sampai memakan korban nyawa.

Berikut kerjasama anatara antara sekolah, orang tua dan polsek untuk mencegah dan meminimalisir perkelahian 
antar pelajar di Kecamatan ParungKabupaten Bogor dalam sebuah wadah satgas pelajar.

\section{Perencanaan Kerjasama}

Proses kerjasama diawali dari adanya kehendak bersama untuk menciptakan lingkungan yang tertib, aman dan nyaman bagi siapa saja yang berada di wilayah parung. Perencanaan kerjasama dilakukan melalui beberapa tahapan:

a. Membangun kesamaan persepsi pentingnya kehidupan yang tertib aman dan nyaman bagi siapa saja.

b. Sebuah bentuk implementasi dari ditandatanganinya nota kesepahaman antara dinas pendidikan kabupaten

bogor dengan polres bogor dibentuknya satgas pelajar.

c. Mengidentifikasi kebutuhan atau analisis kebutuhan

d. Mendaftar komonen-komponen/unsur yang perlu dilibatkan didalam satgas pelajar.

e. Menyusun program satgas pelajar, dan program tindakan yang perlu dilakukan sesuai dengan peran masing-masing. Misalnya:

1) Polsek mengagendakan setiap awal ajaran baru/awal masuk sekolah memberikan himbauan ke sekolahsekolah dengan menjadi Pembina upacara.

2) Polsek mengagendakan jadwal apel rutin dan terprogram, patroli keamanan di daerah-daerah yang rawan tawuran dan waktu-waktu rawan tawuran.

3) Sekolah mengagendakan sweeping barang bawaan siswa secara tibatiba atau mengecek ketika masuk kedalam gerbang.
4) Sekolah mendata siswa-siswa, memetakan siswa yang ada indikasi tawuran kemudian siswa yang bersangkutan untuk selanjutnya dilakukan pembinaan oleh polsek setempat.

5) Sekolah menyusun program kerja antar sekolah, dalam rangka silaturahim mempererat hubungan dengan menyelenggarakan kegiatan bersama yang positif misalnya futsal bersama, bulu tangkis bersama, pengajian, dan lain-lain.

\section{Pengorganisasian Kerjasama}

a. Menyusun tim teknis

b. Menyusun job des dan pembagian piket

c. Pembuatan jadwal rapat penyegaran secara rutin

\section{Pelaksanaan Kerjasama}

Sesuai dengan perencanaan yang sudah dibuat dan diorganisasikan kerjasama dilaksanakan meliputi beberapa hal yakni menyangkut tindakan-tindakan yang perlu dilakukan mulai dari

a. Tindakan pencegahan

b. Tindakan pengawasan

c. Penindakan

\section{Pengendalian/Pengawasan / Evaluasi Kerjasama}

Evaluasi kerjasama dilaksanakan baik oleh masing-masing pihak dengan melihat dampak dari dibentuknya satgas pelajar, maupun dilakukan secara bersama-sama sebagai wujud refleksi tindakan yang telah dilakukan dengan hasil yang didapatkan. Yakni tawuran bisa di cegah dan diminimalisir.

Model faktual penerapan manajemen kerjasama anatar sekolah, 
orang tua dan polsek untuk mencegah dan Kecamatan Parung-Kabupaten Bogor meminimalisir perkelahian antar pelajar di

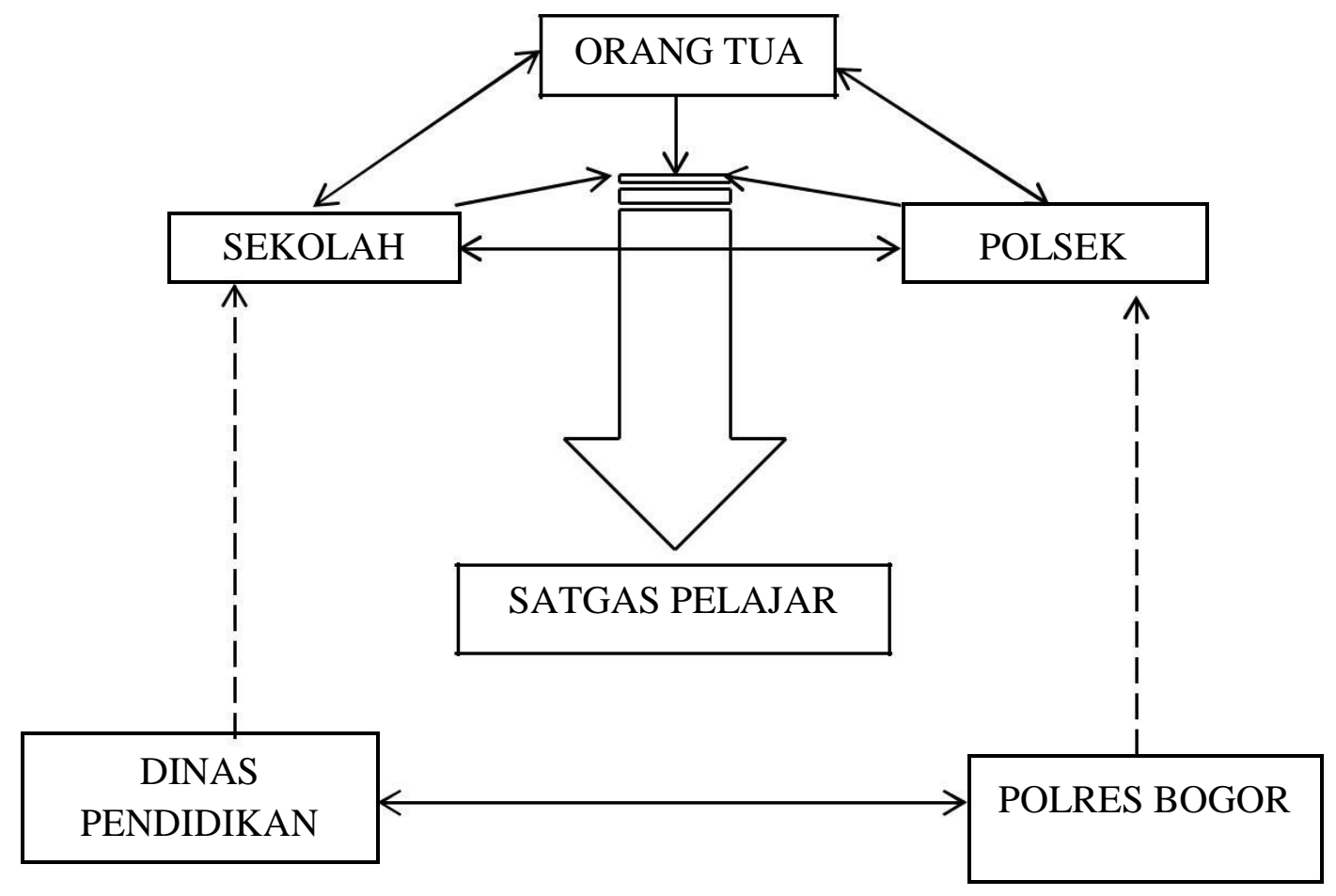

Model faktual penerapan kerjasama anatara sekolah, orang tua dan polsek untuk mencegah dan meminimalisir perkelahian antar pelajar akan didapatkan hasil yang optimal apabila masing-masing pihak dengan penuh kesadaran untuk saling mendukung dan bekerjasama, bersinergi dengan strategi yang tentunya mampu memberikan langkah dana arah gambara yang logis. Dibawah ini peneliti sajikan gambar model dinamis kerjasama anatara sekolah, orang tua dan polsek untuk mencegah dan meminimalisir perkelahian antar pelajar.

Berdasarkan gambar di atas dapat dijelaskan bahwa, kasus tawuran pelajar memiliki beberapa tingkatan, sehingga penanganan yang dilakukan juga berbeda untuk setiap kasusnya. Ada beberapa hal yang menyebabkan perbedaan penangan. Pertama, dapat dilihat dari tingkat kasunya ringan, sedang atau parah. Kedua, dapat dilihat dari siapa yang menjumpai peristiwa tawuran, masyarakat, sekolah, atau langsung polsek.

Pada kasus model dinamis diatas hubungan kerjasama bisaterjadi melibatkan ketiga unsur tersebut yakni Polsek, sekolah dan orang tua bahkan masyarakat atau lembaga sosial. Kerjasam juga bisa hanya terjadi antara orang tua dengan polsek, orang tua dengan sekolah, sekolah dengan sekolah, orang tua dengan orang tua.

Hadirnya satgas pelajar dalam gambar di atas adalah akibat dari konsekuensi bahwa tawuran merupakan persoalan bersama yang membutuhkan kerjasama bersama-sama oleh seluruh 
apparat pemerintah, apparat keamanan terdiri dari unsur polisi, sekolah dan dan masyarakat, maka dinas pendidikan masyarakat. Namun, satags pelajar antar melakukan kerjasama dengan polres kecamatan, antar polsek juga bekerjasama selanjutnya ditindak lanjuti oleh masing- karena tawuran terkadang terjadi masing polsek dan sekolah dibentuklah lingkupnya antar kecamatan, tidak hanya disetiap kecamatan satgas pelajar yang sebatas dalam satu kecamatan saja.

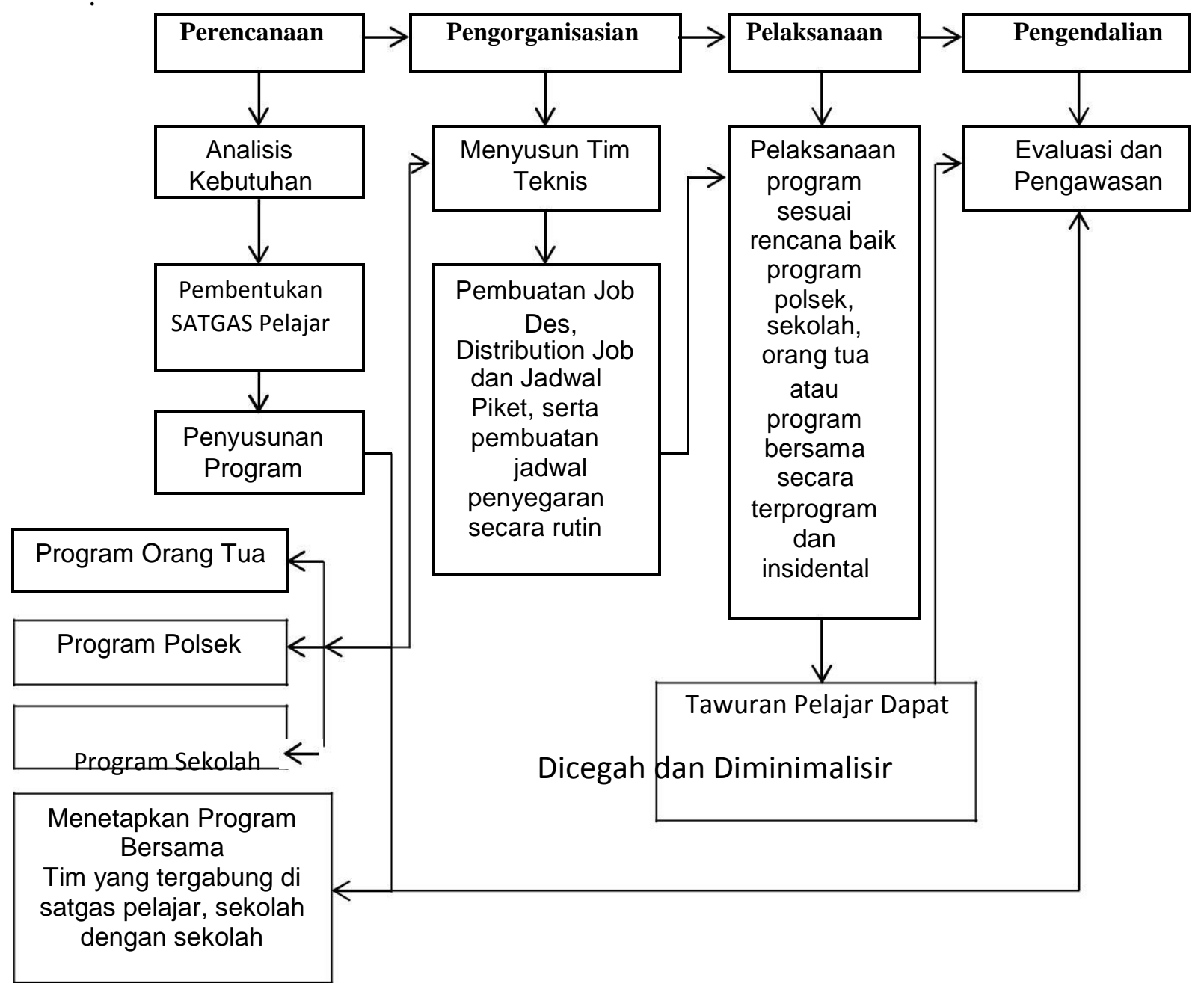

Berdasarkan model faktual di atas, tawuran dapat dicegah dan diminimalisir manakalah masing-masing komponen bekerjasama berperan dengan komitmen dan spirit yang sama.

Kerjasama yang dibangun oleh Polsek parung dengan sekolah-sekolah diwilayah parung terbukti mampu mencegah dan meminimalisir tawuran. Sebagaimana ungkap Kapolsek Parung Bapak Parmin ketika ditemui peneliti di ruang kerjanya beliau mengatakan bahwa "selama saya ditugaskan disini tidak menjumpai tawuran yang dilakukan oleh sekolahsekolah di wilayah parung. Adapun tawuran justru pelakunya adalah sekolahsekolah dari luar kecamatan parung”. Demikian halnya yang peneliti amati dari tahun-ketahun sejak 2013 hingga kini 2018 penelitian ini dilakukan tawuran 
pelajar diwilayah parung nyaris terdengar di telinga. Adapun tawuran pelajar terjadi di wilayah parung. Kondisi tersebut tidak terlepas dari peran dari pada seluruh komponen yang tergabung di dalam satgas pelajar dan masyarakat parung.

\section{SIMPULAN}

Berdasarkan hasil penelitian dan pembahasan dapat diambil kesimpulan sebagai berikut: (1) Manajemen kerjasama yang dibangun oleh polsek, sekolah dan orang tua dalam bentuk formal maupun non formal dalam sebuah wadah satgas pelajar, direncanakan, diorganisasikan, dilaksanakan dan dievaluasi. Terbukti mampu mencegah dan meminimalisisr tawuran pelajar. (2) Model Faktual manajemen kerjasama yang dibangun merupakan model yang sudah selayaknya dibentuk, dirawat sampai tidak ditemukanya gejala akan adanya tawuran atau tawuran pelajar.

Berdasarkan hasil penelitian diatas, saran yang dapat diberikan adalah:

(1) Perlu dibangun sebuah mindset bersama bahwa kehidupan yang tertib aman dan nyaman adalah cita-cita bersama; (2) Bagi POLSEK parung saran yang diberikan kegiatan yang sudah baik untuk ditingkatkan dan disebarkan agar dapat menjadi contoh bagi wilayah (sharing knowledge) lain yang mengalami problematika lingkungan yang hampir sama, sama atau bahkan lebih parah lagi;

(3) Bagi sekolah-sekolah diwilayah parung kerjasama dengan berbagai pihak sebagai wujud kapabilitasnya sebagai sekolah perlu terus dilakukan, dijaga dan dirawat; (4) Bagi orang tua tanggung jawab mendidik anak bukan semata-mata semuanya menjadi beban sekolah, tetapi peran orang tua hendaknya lebih besar dibandingkan sekolah, sebab berbagai penyimpangan yang dilakukan siswa terkadang disebabkan karena luputnya perhatian orang tua terhadap anaknya; (5) Bagi masyarakat, terciptanya kehidupan yang tertib, aman dan nyaman hendaknya menjadi visi bersama semua masyarakat. Mulai dari kesadaran diri kemudian disebarkan agar menjadi kesadaran kolektif bagi seluruh masyarakat; (6) Bagi siswa, jadilah siswa yang berkarakter, berakhlak muliah, dan STOP tawuran pelajar, karena siswa punya masa depan.;

(7) Bagi peneliti hasil penelitian ini dapat dijadikan salah satu rujukan untuk

penelitian berikutnya misalnya menerjemahkan variabel-variabel yang ada di dalamnya kemudian dilakukan penelitian dengan metode kuantitatif atau mix method; (8) Bagi dinas pendidikan, hasil penelitian ini dapat dijadikan salah satu media untuk menyampaikan pesan kebaikan (good massage) kepada seluruh pihak yang berkepentingan bahwa untuk mengatasi maraknya tawuran pelajar perlu kebersamaan; (9) Bagi pemerintah, diperlukan regulasi khususnya dalam penanganan kasus tawuran pelajar. Bahkan pemerintah perlu menyediakan anggaran khusus untuk mengatasi persoalan tawuran pelajar.

DAFTAR RUJUKAN

Adi, Rianto. 2004. Metodologi Penelitian Sosial dan Hukum. Jakarta: Granit Agung Jaya Surahman, I Gede. 2016. Cegah Kenakalan Remaja Melalui Pendidikan Karakter. Jurnal 
Penjamin Mutu Fakultas pada Dharma Acarya IHDN Denpasar Anwar, Zainul. 2015. Strateg Penyelesaian Konflik Antar Teman Sebaya Pada Remaja. Makalah Seminar Psycologi dan Kemanusiaan Fakultas Psikologi Universitas Muhammadiyah Malang Asmani, Jamal. 2012. Kiat Mengatasi Kenakalan Remaja di

Sekolah.Yogyakarta :Buku Bir

Damayanti, Wardyaningrum. 2013.

Komunikasi Untuk Penyelesaian Konflik Dalam Keluarga: Orientasi

Percakapan dan Orientasi

Kepatuhan. Jurnal Al-Azhar

Indonesia Seri Pranata Sosial, Vol 2

No 1 Halaman 47-58

Feryanto, Agung, Hendro Prima Setia dan Aprilia Rachmawati Harjaningrum. 2013. Buku Referensi:Seri Ensiklopedia IPS Materi Ekonomi Manajemen Volume 7. Klaten: Cempaka Putih

Harold T. Amrine, John A. Ritchey, Oliver S. hulley and Sedyana. 1985.

Manajemen dan Organisasi Produksi (Terjemahan edisi keempat). Jakarta:Erlangga

Heri Daryono. 2014. Manajemen Kerjasama Antara Sekolah Menengah Kejuruan dengan Dunia Industri. Jurnal Educational Management.

http://journal.unnes.ac.id/sju/index.p hp/eduman, 3(2): 94-98

Kaelan. 2005. Metode Penelitian Kualitatif Bidang Filsafat. Yogyakarta: Paradigma.

Miles, B Matthew \& A. Michael Huberman. 1992. Analisis Data kualitatif ( Terjemahan Teecep

Rohendi). Jakarta: UI Press.

Moleong, Lexy. 2006. Metodologi Penelitian Kualitatif. Bandung: PT. Remaja Rosda Karya.

Nasution. 2003. Metode Penelitian Naturalistik Kualitatif. Bandung: Tarsito

Oktima, Nurul. 2012. Kamus Ekonomi. Surakarta:PT. Aksarra Sinergi Media

Septian Bayu Rismanto, dkk. 2012. Model Penyelesaian Tawuran Antar Pelajar Sebagai Upaya Mencegah Terjadinya Degradasi Moral Pelajar (Studi Kasus di Kota Blitar-Jawa

Timur). Artikel Penelitian. Universitas Negeri Malang. http://jurnal-

online.um.ac.id/data/artikel/artikel83 97075D9A060ECD40D06CBEEF53 3ECD.pd (Diakses Minggu, 3 April 2017 Pukul 18.30 WIB)

Sutomo, dkk. 2007. Manajemen Sekolah.

Semarang: UPT Percetakan dan Penerbitan MKK UNNES PRESS

Suyanto, Bagong dan Sutinah. 2005. Metode Penelitian Sosial Berbagai Alternatif Pendekatan. Jakarta: Kencana Prenanda Media Group.

Wiyanto. 2016. Analisis Penerapan Manajemen Pengetahuan dan Pengetahuan Berbasis Strategi Untuk Menciptakan Keunggulan Bersaing Berkelanjutan (STudi Kasus SMK YPUI Parung). Tesis. Program Pascasarjana Program Studi Manajemen Universitas PamulangTangerang Selatan. 
Internet:

https://m.tempo.co/read/news/2015/04/07/

064655897/10-daerah-rawan-

tawuran-pelajar-di-bogor (diakses

minggu 3 April 2017 Pukul 18.30

WIB)

http://www.beritasatu.com/aktualitas/2464

33-parung-darurat-tawuran- pelajar.html (diakses minggu 3 April 2017 Pukul 18.30 WIB)

https://www.merdeka.com/peristiwa/pelaj ar-smk-di-parung-tewas-dibacokusai-dikeroyok-sekelompokabg.html (diakses minggu 3 April 2017 Pukul 18.3 
